\title{
PENGAIRAN SAWAH TEPI ALIRAN SUNGAI DENGAN POMPA OTOMATIS MEMANFAATKAN TENAGA ALIRAN SUNGAI DI KABUPATEN TANA TORAJA
}

\author{
(KAJIAN LITERATUR)
}

\author{
Alexander Pakiding ${ }^{1}$, Yulius Pakiding ${ }^{2}$
}

${ }^{1}$ Prodi Matematika FKIP, UKI Toraja, alex_pakiding@yahoo.com

2 Prodi Teknik Sipil Fakultas Teknik, UKI Toraja, yulius_pakiding@yahoo.co.id

\begin{abstract}
Abstrak
Sebagian sawah yang ada di Kabupaten Tana Toraja berada di Daerah Aliran Sungai (DAS), yaitu berada sekitar 3 - 10 meter di atas permukaan aliran air sungai. Walaupun demikian sebagian sawah tersebut tidak mendapatkan aliran air irigasi sehingga tidak produktif di saat musim kemarau. Salah satu solusi untuk menangani masalah tersebut adalah dengan pengairan pompanisasi otomatis memanfaatkan tenaga arus sungai sehingga diharapkan sawah tersebut dapat berproduksi sepanjang tahun dan pendapatan petani meningkat.
\end{abstract}

Kata Kunci : Arus sungai, pompanisasi otomatis, pengairan.

\section{A. Pendahuluan}

Tana Toraja terbentang mulai dari Km. 280 sampai Km. 355 dari sebelah utara ibukota Propensi Sulawesi Selatan (Makassar.) Tepatnya pada $2^{\circ}-3^{\circ} \mathrm{LS}$ dan $199^{\circ}-120^{\circ} \mathrm{BT}$, dengan luas sekitar 3.205,77 $\mathrm{Km}^{2}$ atau sekitar 5\% dari luas Propensi Sulawesi Selatan.

Kabupaten Tana Toraja adalah daerah pegunungan yang berada di ketinggian berkisar antara $700 \mathrm{~m}$ hingga $1425 \mathrm{~m}$ di atas permukaan laut yang secara rinci seperti pada tabel 1 berikut;

Tabel I. Tinggi Wilayah di atas Permukaan Laut (DPL) menurut Kecamatan di Kabupaten Tana Toraja tahun 2011-2013, sebagai berikut.

\begin{tabular}{|l|l|r|r|r|}
\hline \multirow{2}{*}{ No } & Kecamatan & \multicolumn{3}{|c|}{ Tahun } \\
\cline { 3 - 5 } & & $\mathbf{2 0 1 1}$ & $\mathbf{2 0 1 2}$ & $\mathbf{2 0 1 3}$ \\
\hline 1. & Bonggakaradeng & 920 & 920 & 920 \\
2. & Simbuang & 1378 & 1378 & 1378 \\
3. & Rano & 700 & 700 & 700 \\
4. & Mappak & 1088 & 1088 & 1088 \\
5. & Mengkendek & 974 & 974 & 974 \\
6. & Gandang Batu Sillanan & 980 & 980 & 980 \\
7. & Sangalla & 817 & 817 & 817 \\
8. & Sanggalla Selatan & 781 & 781 & 781 \\
9. & Sangalla Utara & 781 & 781 & 781 \\
10 & Makale & 760 & 760 & 760 \\
11 & Makale Selatan & 736 & 736 & 736 \\
12 & Makale Utara & 820 & 820 & 820 \\
13 & Saluputti & 853 & 853 & 853 \\
14 & Bittuang & 1425 & 1425 & 1425 \\
15 & Rembon & 762 & 762 & 762 \\
16 & Masanda & 864 & 864 & 864 \\
17 & Malimbong Balepe & 859 & 859 & 859 \\
18 & Rantetayo & 884 & 884 & 884 \\
19 & Kurra & 882 & 882 & 882 \\
& & & & \\
\hline & Sumber: Badan Pusat Stratistik Kabupaten Tana Toraja \\
\hline
\end{tabular}

Grafik 1. Rata-rata Curah Hujan Setiap Bulan di Kabupaten Tana Toraja, 2011 - 2013 


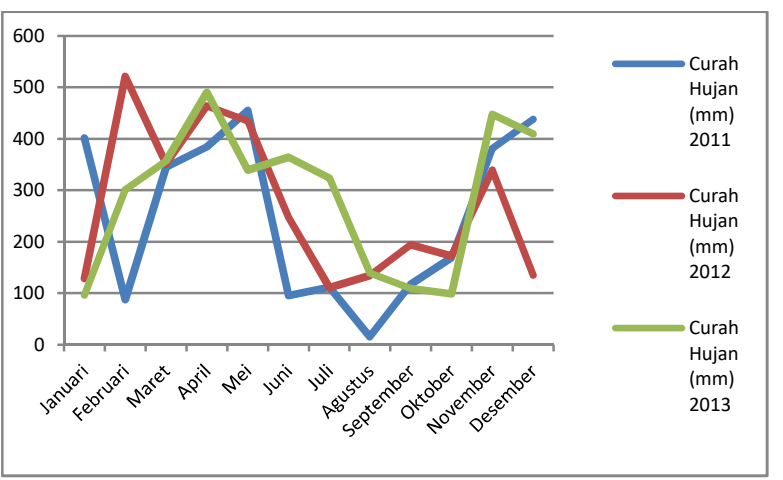

Sumber: BMKG Kabupaten Tana Toraja

Keadaan hidrologi di Kabupaten Tana Toraja dapat diamati dengan adanya air tanah yang bersumber dari air hujan yang sebagian mengalir di permukaan (run off) dan sebagian lagi meresap ke bumi dan sampai ke tempat-tempat yang dangkal, serta sebagian lagi mencapai tempat-tempat yang dalam, dimana sering dikategorikan sebagai air tanah.

Pada umumnya jenis air permukaan yang terdapat di Kabupaten Tana Toraja berasal dari sungai saddang yang merupakan salah satu sungai terpanjang yang berada di Sulawesi Selatan serta beberapa sungai-sungai yang mengalir di wilayah tersebut diantaranya sungai Mai'ting, sungai Saluputti, sungai Maulu, sungai Surame, sungai Sarambu yang pada umumnya bersumber dari mata air pegunungan. Untuk jenis air ini sebagian besar dipergunakan untuk keperluan pertanian, pariwisata (arung jeram) dan rumah tangga, sedangkan untuk air tanah dangkal dapat diperoleh dari sumur gali dengan kedalaman sekitar 10 - 15 meter dengan kualitas airnya cukup memenuhi syarat-syarat kesehatan. Untuk jenis air ini dipergunakan oleh sebagian besar masyarakat sebagai sumber air untuk keperluan rumah tangga. http://www.tanatorajakab .go.id/en/content/ hidrologi

Lahan Sawah (wetland) dengan luas $10.761 \mathrm{Ha}$, kategori penggunaan lahan ini hampir merata disemua kecamatan. Penggunaan lahan ini diperuntukkan sebagai areal persawahan dengan perincian: pengairan sederhana PU seluas $521 \mathrm{Ha}$, pengairan non PU $3.187 \mathrm{Ha}$, sawah tadah hujan dan lainnya seluas $7.053 \mathrm{Ha}$.

Grafik 2. Luas wilaya kecamatan di Kabupaten Tana Toraja

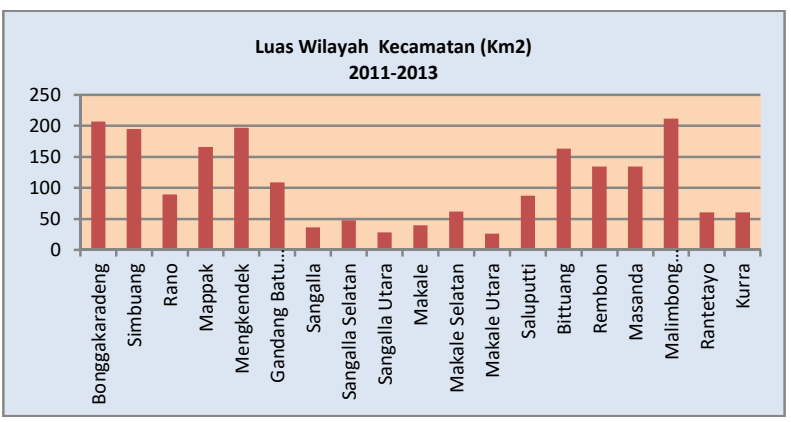

JDS, Jilid II No. 2, Oktober 2016

Sumber: Badan Pusat Stratistik Kabupaten Tana Toraja

\section{Latar Belakang}

Pengairan yang ada di Tana Toraja jangkauannya sangat terbatas karena kontur tanah yang tidak memungkinkan. Untuk menjangkau lahan yang ada di daerah aliran sungai harus dibangun bendungan lebih banyak. Kendala yang muncul adalah biaya untuk membangun bendungan sangat besar sehingga sulit terealisasi.

Ketika musim kemarau tiba ( bulan Juli - Oktober ), lahan persawahan yang tidak mendapatkan air irigarisi mengalami kekering, termasuk sebagian lahan yang letaknya di Daerah Aliran Sungai (DAS) yang belum teraliri air irigasi juga ikut kering. Hal ini berdampak pada nilai produksi yang bisa diperoleh dari lahan tersebut.

\section{Rumusan Masalah}

Berdasarkan latar belakang di atas maka masalahnya adalah bagaimana mengatasi keterbatasan pengairan yang ada di Kabupaten Tana Toraja khususnya di Daerah Aliran Sungai sehingga dapat dimaksimalkan pemanfaatannya.

\section{Tujuan}

Tulisan bertujuan untuk : Mencari solusi mengatasi kekurangan air untuk lahan di Daerah Aliran Sungai (DAS), sehingga petani dapat memanfaatkan lahan tersebut sepanjang tahun semaksimal mungkin sehingga pendapatannya bisa meningkat demi kesejahteraan hidup mereka dengan kajian ilmu pengetahuan khususnya fisika untuk memanfaatkan kekayaan alam semaksimal mungkin bagi masyarakat petani.

\section{B. Metodologi}

Dalam penelitian ini ditempuh langkah-langkah: pengamatan lapangan, perumusan masalah dan keajian literatur

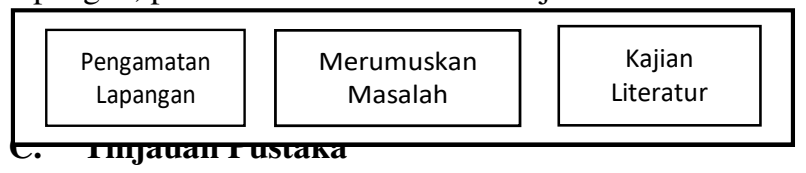

\section{Aliran Sungai}

Kabupaten Tana Toraja merupakan daerah pegunungan, sehingga arus aliran sungai yang ada di kabupaten ini umumnya masih deras. Hal ini sangat mendukung untuk menerapkan pengairan system ini karena dengan demikian aliran memiliki energi yang cukup untuk memutar pompa yang memompa air ke persawahan yang ada disekitar aliran sungai.

Besarnya tenaga air yang tersedia dari suatu sumber air bergantung pada ketinggian $(h)$, debit air $(Q)$, kecepatan aliran $(v)$ dan luas penampang $(A)$. Energi potensial pada air yang jatuh dari ketinggian tertentu dirumuskan sebagai berikut

$$
E=m g h
$$


dengan ;

$m$ adalah massa air

$h$ adalah ketinggian

$g$ adalah percepatan gravitasi $\left(\frac{m}{s^{2}}\right)$

Daya adalah energi tiap satuan waktu $\left(\frac{E}{t}\right)$, sehingga persamaan (1) dapat dinyatakan sebagai :

$$
\left(\frac{E}{t}\right)=\frac{m}{t} g h
$$

Dengan mensubsitusikan $P$ terhadap $\left(\frac{E}{t}\right)$ dan mensubsitusikan $\rho Q$ terhadap $\left(\frac{m}{t}\right)$ maka :

$$
P=\rho Q g h
$$

dengan ;

$$
\begin{aligned}
& P \text { adalah daya (watt) yaitu } \\
& Q \text { adalah kapasitas aliran }\left(\frac{\mathrm{m}^{3}}{\mathrm{~s}}\right) \\
& \rho \text { adalah densitas air }\left(\frac{\mathrm{kg}}{\mathrm{m}^{3}}\right)
\end{aligned}
$$

Selain memanfaatkan air jatuh hydropower dapat diperoleh dari aliran air datar. Dalam hal ini energi yang tersedia merupakan energi kinetic

$$
E=\frac{1}{2} m v^{2}
$$

dengan ;

$$
v \text { adalah kecepatan aliran air }\left(\frac{m}{s}\right)
$$

Daya air yang tersedia dinyatakan sebagai berikut: kontinuitas

$$
P=\frac{1}{2} \rho Q v^{2} \text { atau dengan menggunakan persamaan }
$$

dengan;

$$
Q=A v \text { maka, } \quad P=\frac{1}{2} \rho A v^{3}
$$

$A$ adalah luas penampang aliran air $\left(\mathrm{m}^{2}\right)$

Daya yang dimiliki oleh air ini akan dimanfaatkan untuk memutar pompa air sebagai pengganti tenaga listrik.

\section{Pompa Air}

Pompa air terdiri atas 3 (tiga) bagian utama yaitu:

a. Dinamo yang berfungsi untuk mengubah energy listrik menjadi energy putar untuk memutar kipas/balingbaling pompa.

b. Kipas/baling-baling yang berfungsi untuk memompa air.

c. Pipa, yang berfungsi sebagai media alir yang diletakkan pada dua posisi yang berbeda dimana yang satu berfungsi sebagai aliran tarik (isap), dan yang satu berfungsi untuk aliran dorong (buang).

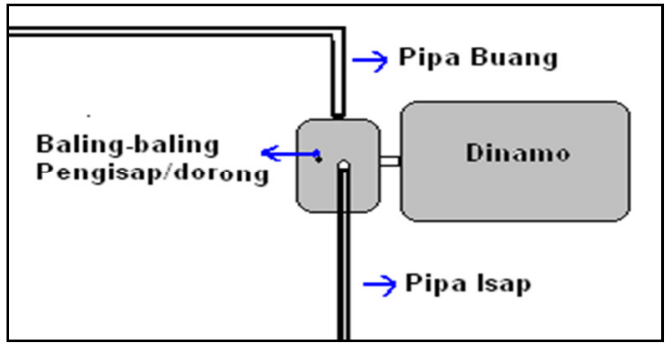

Gambar 1. Bagian - bagian pompa air

Prinsip kerja dari pompa ini adalah; dinamo memutar balingbaling/kincir sehingga air yang ada dalam pipa bagian bawah akan terhisap dan kemudian didorong ke pipa buang.

\section{Kecepatan Aliran dan Kecepatan Putaran}

Sesuai dengan hukum kontiunitas $Q=A v$ yang berarti bahwa kecepatan $(v$ dalam $\mathrm{m} / \mathrm{dt}$ ) aliran dapat ditingkatkan dengan memperkecil luas penampang $\left(A\right.$ dalam $\left.\mathrm{m}^{2}\right)$ karena debit $\left(Q\right.$ dalam $\left.\mathrm{m}^{3} d t\right)$ tetap. Hal ini dapat dilakukan dengan memodifikasi aliran yaitu dengan menggunakan bangunan bentuk corong seperti gambar 2 berikut. Air mengalir dari $A_{1}$ ke $A_{2}$ dimana $A_{1}>A_{2}$ sehingga sesuai dengan rumus kuntiunitas di atas maka $v_{2}>v_{1}$

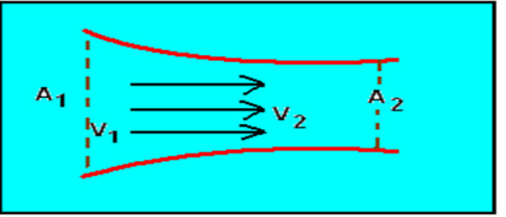

Gambar 2. Prinsip Kontinuitas Aliran Fluida

Selain cara di atas, kecepatan putaran dapat ditingkatkan dengan menggunakan prinsip roda gigi.

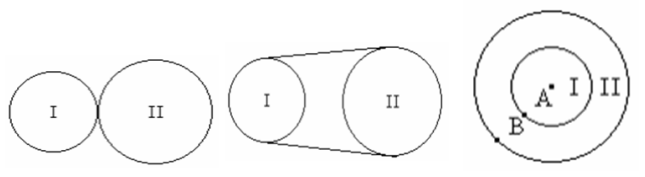

(a)

(b)

(c)

uamoar 5. sistem roaa gigi

a) Sistem bersinggungan langsung

b) Sistem setali

c) Sistem sesumbu

Dari gambar 3a. (sistem bersinggungan langsung) dimana roda I memiliki jari-jari lebih kecil jari-jari roda II. Jika salah satu dari roda ini diputar maka keduanya akan berputar dengan arah yang berlawanan dan memiliki kecepatan linear yang sama tetapi kecepatan sudutnya berbeda. Jadi $v_{1}=v_{2}$, $w_{1} \neq w_{2}$. Dimana;

$$
\begin{aligned}
& v_{1}=r_{1} w_{1}, v_{2}=r_{2} w_{2}, \text { jadi } \\
& r_{1} w_{1}=r_{2} w_{2}
\end{aligned}
$$


Karena jari-jari roda II lebih besar maka kecepatan sudutnya lebih kecil dibandingkan dengan kecepatan sudut roda I. Artinya roda yang jari-jarinya lebih kecil (roda I) akan berputar lebih banyak dibanding roda II yang jari-jarinya lebih besar.

Untuk gambar 3b (system setali), jika jari-jari roda I dan II sama maka kecepatan linea.r dan kecepatan sudutnya akan sama. Tetapi jika seperti pada gambar dimana jari-jari roda I lebih kecil disbanding roda II maka kecepatan linearnya sama $\left(v_{1}=v_{2}\right)$ tetapi kecepatan sudutnya tidak sama $w_{1} \neq w_{2}$ dan arah putarnya searah.

Jika roda-roda tersebut disusun dalam satu poros putar gambar 3.c, maka titik-titik yang terletak pada satu jari-jari pada system tersebut, mempunyai kecepatan anguler yang sama, tetapi kecepatan liniernya tidak sama. $\omega_{A}=\omega_{B}$ tetapi $V_{a} \neq V_{B}$.

\section{Penggunaan Lahan sawah di Daerah Aliran Sungai}

Sebagian lahan sawah di Daerah Alliran Sungai (DAS) di Kabupaten Tanah Toraja dan Kabupaten Toraja Utara belum mendapatkan aliran air pengairan. Keadaan sawah ini tidak jauh beda dengan sawah yang lain yang ada di Tana Toraja, yaitu sebagai sawah tadah hujan. Jika saat musim kemarau lahan ini juga tidak dapat diolah oleh pemiliknya karena ikut mengalami kekeringan. Jadi sawah-sawah juga tidak produktif walaupun air ada hanya sekitar 3 samap 6 meter dibawahnya. Hal ini tentu sangat disayangkan karena sebenarnya jika airnya cukup sepanjang tahun maka sawah tersebut selain dimanfaatkan sebagai lahan untuk menanam padi juga dapat dimanfaatkan sebagai lahan untuk memelihara ikan, menanam sayur-mayur yang di kedua kabupaten ini banyak didatangkan dari kabupaten lain seperti Luwu atau Enrekang.

\section{Pembahasan}

Sawah di Daerah Aliran Sungai (DAS) yang dimaksudkan dalam hal ini adalah sawah yang terletak di sekitar aliran sungai dan tidak terlalu tinggi.

Pengairan yang ada saat ini kebanyakan dibuat dengan membendung aliran sungai hingga air sungai dapat di alitkan ke persawahan. Tentu cara ini memerlukan biaya yang cukup besar dan jika lahan persawahan yang akan di aliri tidak terlalu luas maka dipandang tidak ekonomis.

Salah satu solusi yang dapat digunakan untuk mengatasi masalah tersebut adalah dengan memanfaatkan aliran sungai untuk memutar pompa yang akan memipa air sungai itu ke daerah persawahan tersebut. Pompa ini akan bekerja sepanjang masih ada aliran yang cukup untuk memutar pompa tersebut (Pompa Otomatis), tidak menggunakan bahan bakar dan listrik sehingga tidak membebani petani.

Pengairan Pompa Otomatis dengan tenaga arus aliran sungai pada prinsipnya sama dengan pembangkit listrik tenaga air. Dalam hal ini tenaga aliran atau energy kinetic yang dimiliki oleh air diubah menjadi energy putar. Jika pada
JDS, Jilid II No. 2, Oktober 2016

pembangkit listrik putaran ini digunakan untuk memutar generator untuk membangkitkan listrik, maka pada pompa otomatis untuk pegairan dimanfaatkan untuk memutar pompa yang akan menghisap dan mendorong air ke tempat yang di inginkan sesuai dengan kemampuan yang dimiliki pompa tersebut.

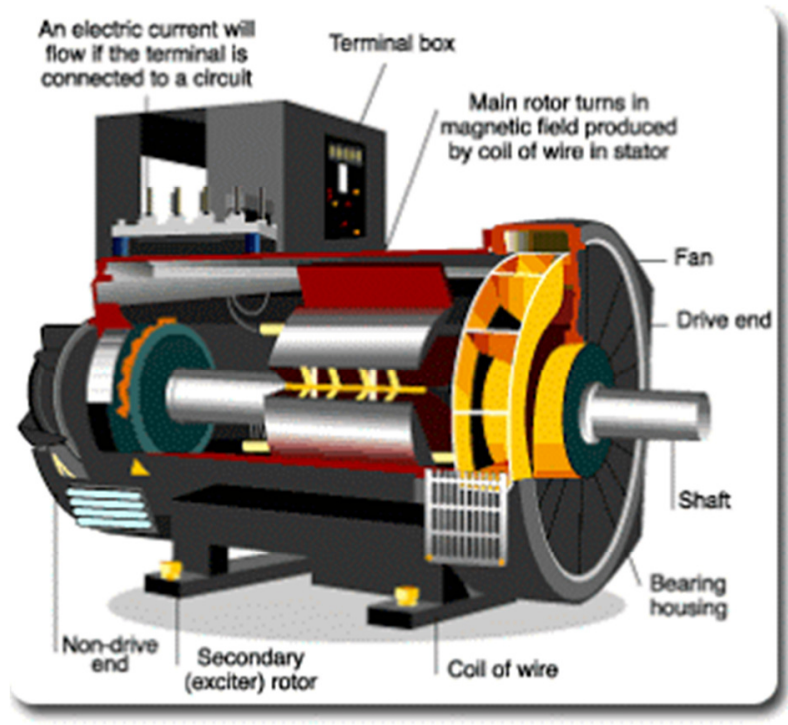

Gambar 4. Pembangkit Listrik Tenaga Air (Albert Charlos, Tribunnews)

Pompa Otomatis dengan tenaga arus sungai dapat menggunakan pompa air listrik dengan melepas dinammonya (generatornya). Kemudian pada bagian generator diganti dengan gir untuk disambung ke kincir yang nantinya akan diputar oleh arus sungai rangkaian seperti pada gambar 6 . Untuk mendapatkan putaran

yang sesuai dengan yang kita inginkan maka digunakan beberapa cara.

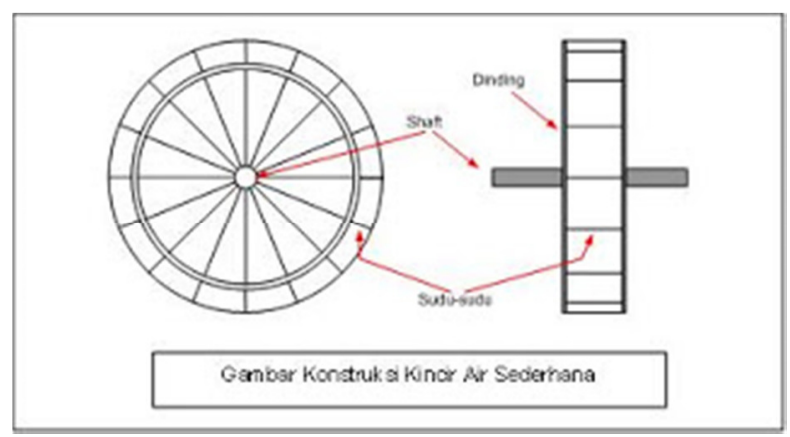

Gam bar 5. Kinc ir air (Alb ert Char los, Trib unne ws )

Untuk aliran air pada sungai yang relative datar dapat dirancang suatu alat untuk mendapatkan kecepatan alir yang memadai yaitu dengan memanfaatkan prinsip kontinuitas ; debit air yang masuk $Q_{1}=A_{1} V_{1}$ sama dengan debit air yang keluar $Q_{2}=A_{2} V_{2}$. Jadi $A_{1} V_{1}=A_{2} V_{2}$, sehingga apabila luas penampang $A_{2}$ diperkecil akibatnya adalah $V_{2}$ menjadi besar 
atau akan diperoleh kecepatan pada aliran keluaran lebih besar dibanding pada saat masuk (gambar 2).

Kecepatan juga dapat kita tingkatkan dengan memanfaatkan multiple pulley (pulley bertingkat)

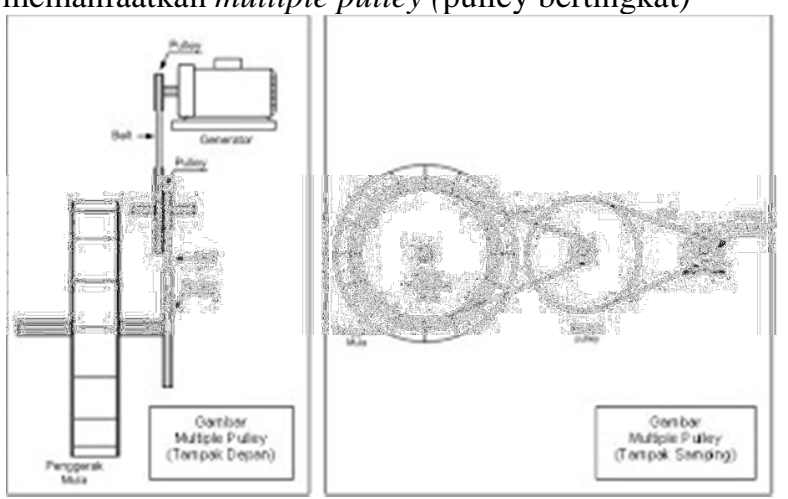

Gambar 6. Pulley bertingkat

(Albert Charlos, Tribunnews)

Dengan menggunakan Pulley bertingkat seperti pada gambar di atas maka kecepatan putaran pompa dapat ditingkatkan.

Kecepatan arus aliran, jari-jari kincir dan jari-jari gir merupakan variabel yang dapat kita ubah sesuai dengan yang kita harapkan (Tabel 2). Sedangkan kecepatan arus aliran di sini kita dapat kita ubah dengan menggunakan prinsip kontinuitas.

Dari data pada tabel tersebut terlihat bahwa walaupun kecepatan arus sungai tidak terlalu besar tetapi dengan mengunakan pulley bertingkat kita dapat meningkatkan putaran untuk memutar pompa sesuai yang diinginkan. Jari-jari kincir dapat perbesar dengan tujuan untuk memperbesar torsi $(\tau=F \times L)$. jadi dengan gaya yang sama kita dapat meningkatkan torsi putaran sehingga mampu memutar pompa yang terpasang. Gir dengan jari-jari $r_{22}$ jika diperbesar akan berdampak pada frekuensi putara pompa $\left(f_{3}\right)$, dimana semakin tinggi $\left(f_{3}\right)$ semakin kuat daya dorong/daya tarik pompa tersebut, Jadi ketinggian lahan persawahan yang akan di aliri dapat kita jangkau dengan mengatur kecepatan putaran pompa.

Tabel 2. Perbandingan kecepatan putaran turbin dan pompa

\begin{tabular}{|c|c|c|c|c|c|c|c|c|c|c|c|c|}
\hline No. & $\begin{array}{l}V 1= \\
V 21\end{array}$ & $\begin{array}{c}R I \\
(\boldsymbol{m})\end{array}$ & $\begin{array}{c}R 21 \\
(m)\end{array}$ & $\begin{array}{c}R 22 \\
(m \\
)\end{array}$ & $\begin{array}{l}R 31 \\
(m)\end{array}$ & $\omega_{1}$ & $\begin{array}{r}\omega_{21} \\
=\omega_{22}\end{array}$ & $\begin{array}{c}v_{22} \\
=v_{31}\end{array}$ & w3 & $\begin{array}{l}f 1 \\
(1 / s)\end{array}$ & $\begin{array}{l}f 2 \\
(1 / s)\end{array}$ & $\begin{array}{l}f 3 \\
(1 / s)\end{array}$ \\
\hline 1 & 0 & 0.5 & 0.03 & 0.3 & 0.03 & 0.0 & 0.0 & 0.0 & 0.0 & 0.0 & 0.0 & 0.0 \\
\hline 2 & 0.1 & 0.5 & 0.03 & 0.3 & 0.03 & 0.2 & 3.3 & 1.0 & 33.3 & 0.0 & 0.5 & 5.3 \\
\hline 3 & 0.2 & 0.5 & 0.03 & 0.3 & 0.03 & 0.4 & 6.7 & 2.0 & 66.7 & 0.1 & 1.1 & 10.6 \\
\hline 4 & 0.3 & 0.5 & 0.03 & 0.3 & 0.03 & 0.6 & 10.0 & 3.0 & 100.0 & 0.1 & 1.6 & 15.9 \\
\hline 5 & 0.4 & 0.5 & 0.03 & 0.3 & 0.03 & 0.8 & 13.3 & 4.0 & 133.3 & 0.1 & 2.1 & 21.2 \\
\hline 6 & 0.5 & 0.5 & 0.03 & 0.3 & 0.03 & 1.0 & 16.7 & 5.0 & 166.7 & 0.2 & 2.7 & 26.5 \\
\hline 7 & 0.6 & 0.5 & 0.03 & 0.3 & 0.03 & 1.2 & 20.0 & 6.0 & 200.0 & 0.2 & 3.2 & 31.8 \\
\hline 8 & 0.7 & 0.5 & 0.03 & 0.3 & 0.03 & 1.4 & 23.3 & 7.0 & 233.3 & 0.2 & 3.7 & 37.2 \\
\hline 9 & 0.8 & 0.5 & 0.03 & 0.3 & 0.03 & 1.6 & 26.7 & 8.0 & 266.7 & 0.3 & 4.2 & 42.5 \\
\hline 10 & 0.9 & 0.5 & 0.03 & 0.3 & 0.03 & 1.8 & 30.0 & $\begin{array}{l}9.0 \\
\end{array}$ & 300.0 & 0.3 & 4.8 & 47.8 \\
\hline 11 & 1 & 0.5 & 0.03 & 0.3 & 0.03 & 2.0 & 33.3 & 10.0 & 333.3 & 0.3 & 5.3 & 53.1 \\
\hline 12 & 1.1 & 0.5 & 0.03 & \begin{tabular}{|l|} 
\\
\end{tabular} & 0.03 & 2.2 & 36.7 & 11.0 & 366.7 & 0.4 & 5.8 & 58.4 \\
\hline 13 & 1.2 & 0.5 & 0.03 & 0.3 & 0.03 & 2.4 & 40.0 & 12.0 & 400.0 & 0.4 & 6.4 & 63.7 \\
\hline 14 & 1.3 & 0.5 & 0.03 & 0.3 & 0.03 & 2.6 & 43.3 & 13.0 & 433.3 & 0.4 & 6.9 & 69.0 \\
\hline 15 & 1.4 & 0.5 & 0.03 & 0.3 & 0.03 & 2.8 & 46.7 & 14.0 & 466.7 & 0.4 & 7.4 & 74.3 \\
\hline 16 & 1.5 & 0.5 & 0.03 & 0.3 & 0.03 & 3.0 & 50.0 & 15.0 & 500.0 & 0.5 & 8.0 & 79.6 \\
\hline 17 & 1.6 & 0.5 & 0.03 & 0.3 & 0.03 & 3.2 & 53.3 & 16.0 & 533.3 & 0.5 & 8.5 & 84.9 \\
\hline
\end{tabular}

JDS, Jilid II No. 2, Oktober 2016

\begin{tabular}{|c|c|c|c|c|c|c|c|c|c|c|c|c|}
18 & 1.7 & 0.5 & 0.03 & 0.3 & 0.03 & 3.4 & 56.7 & 17.0 & 566.7 & 0.5 & 9.0 & 90.2 \\
\hline 19 & 1.8 & 0.5 & 0.03 & 0.3 & 0.03 & 3.6 & 60.0 & 18.0 & 600.0 & 0.6 & 9.6 & 95.5 \\
\hline 20 & 1.9 & 0.5 & 0.03 & 0.3 & 0.03 & 3.8 & 63.3 & 19.0 & 633.3 & 0.6 & 10.1 & 100.8 \\
\hline 21 & 2 & 0.5 & 0.03 & 0.3 & 0.03 & 4.0 & 66.7 & 20.0 & 666.7 & 0.6 & 10.6 & 106.2 \\
\hline
\end{tabular}

Ket :

$\mathrm{V}_{1}=$ kecepatan tangensial kincir (kecepatan arus sungai

$\mathrm{V}_{21}=$ kecepatan gir 21

$\mathrm{V}_{22}=$ kecepatan gir 22

$\mathrm{V}_{3}=$ kecepatan gir 3

$\mathrm{R}_{1}=$ Jari-jari turbin

$\mathrm{R}_{21}=$ Jari-jari gir kecil roda dua

$\mathrm{R}_{22}=$ Jari-jari luar roda dua

$\mathrm{R}_{31}=$ Jari-jari gir pada pompa

$\mathrm{f}_{1}=$ frekuensi kincir

$\mathrm{f}_{2} \quad$ frekuensi roda dua

$\mathrm{f}_{3}=$ frekuensi pompa

\section{E. Kesimpulan}

Sawah di sekitar Daerah Aliran Sungai (DAS) yang selama ini merupakan sawah tadah hujan dapat kita tingkatkan

Dengan memodifikasi kecepatan aliran air sungai menggunakan prinsip kontinuitas dan palley bertingkat kita dapat meningkatkan kecepatannya.

sehingga dapat dimanfaatkan untuk memutar pompa air. yang kekuatan dorong/ isapnya dapat diatur dengan mengubah variabel gear dan kecepatan aliran. Dengan demikian maka salah satu solusi untuk mengatasi keterbatasan pengairan di Kabupaten Tana Toraja adalah dengan pompanisasi otomatis memanfaatkan arus aliran sungai.

\section{F. Saran}

Berdasarkan hasil kajian ini, maka diharapkan ada penelitian lanjutan.

\section{F. Dagtar Pustaka}

[1] Benny Syahputra, Model Pompa Air dengan Tenaga Angin untuk Pemanfaatan Irigasi Sawah, Prosiding SNST ke-4, Fakultas Teknik Universitas Wahid Hasyim, 2013

[2] Dr. Sri Purnomo Sari, Pengaruh Jarak dan Uuran Nozzle pada putaran sudu terhadap daya listrik turbin Pelton,

[3] Charlos, A, Pembangkit Listrik Tenaga Air, Tribunnews 14 April 2014.

[4] Giancolli, Fisika Dasar I, Edisi 5, Erlangga 201.

[5] Kementerian Pertanian Badan Penyuluhan dan Pengembangan SDM Pertanian, Pompa Air Irigasi, Modul, 2015

[6] Yogo Pratisto, Prototipe Pembangkit Listrik Tenaga Air Memanfaatkan Teknologi Sistem Pipa Kapiler, Jurnal Teknik POMITS Vol. 3, No. 1, 2014. 